\title{
A Country-Level Analysis of Worldwide Official Financing by International Financial
}

\author{
Institutions \\ * Abdul Basit (Correspondence Author) \\ ** Tehmina Fiaz Qazi \\ *** Abdul Aziz Khan
}

\begin{abstract}
This study aims to evaluate worldwide official financial flows by international financial institutions to selected 123 countries of the world. The design of the study is composed of a review of literature elicited from research databases, extraction of secondary data of World Development Indicators (WDI) 2020, and mathematical analysis. In real time, cross-sectional country-level data, a classical process of Grey Relational Analysis (GRA) has been applied. Results of the study show that Argentina, Ethiopia, Bangladesh, India, Egypt, Arab Rep., Kenya, Costa Rica, Vietnam, Chad, Tanzania, Colombia, Uzbekistan, Nepal, Indonesia, Nigeria, Rwanda, Cameroon, and Uganda have exceptionally high grey relational grade meaning thereby, having an effective system of obtaining official international financial flows. Zimbabwe, Russian Federation, Botswana, Afghanistan, Bulgaria, South Africa, Burundi, Belarus, Kazakhstan, Armenia, Pakistan, Peru, Romania, and Ukraine have poor grey relational grade meaning thereby, having a relatively weak system of obtaining official financial flows. It is a unique study that provides extensive information on the official financial flows of more than a hundred countries of the world and provides the basis for the informed opinion of policymakers, political governments, economic policymakers, researchers, and academia. It also provides valuable information useful for international financial institu tions.
\end{abstract}

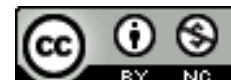

Keywords: Financial Flows, GRA, Institutions, International, Official Financing

\section{Introduction}

In the wake of mass production, mass consumption and enhanced regime of political governments seeking official financing (from international financial institutions and foreign governments) is an integral part of countries' economic policies. International Financial Institutions (IFIs) play a pivotal role in socio-economic development programs in developing nations by way of advising, funding, and assisting the implementation of development projects. IFIs promote regional cooperation, support institutional development and help governments in reducing poverty and improving the living standards of the people. International funding is an issue of fundamental importance and is also high on the agenda of research by mainstream economists. It is a recurring type of research phenomenon demanding afresh investigation. The literature is rich on this topic but country-level comparative analysis of multiple cross-sections with a multitude of criteria compositely can rarely be found in the literature. There is a lot of research on the subject viz: Carnevali et al. (2020) investigated financial flows, society \& ecosystem \& society and economy and claimed an important role of cross-country financial flows in socio-economic development. Adeleke (2019) affirmed that illicit financial flows and resource-dependent states are the major determinants of inequality in Zimbabwe. Bayoumi et al. (2015) proclaimed a positive relationship between lagged net official financial flows (manifested in lagged official assets stock) and current accounts, it is further bolstered that net official flows have a substantial impact on current accounts in constrained international capital flows and relatively lesser effects when international capital flows are highly mobilized. Cova and Natoli (2020) examined the US economy of international financial flows during global financial crises and found autonomous channel existence where both types of financial flows i.e. Global Banking Glut (GBG) and Global Saving Glut (GDG) contributed to a freer financial market through high banking leverage and lower

* Lahore Institute of Science \& Technology, Lahore, Pakistan Email: abasit shahbaz@yahoo.com

** Hailey College of Banking and Finance, University of the Punjab, Lahore, Pakistan

Email: tehmina.qazi@gmail.com

*** Institute of Business and Management, University of Engineering and Technology, Lahore, Pakis tan Email: azizniazi@uet.edu.pk 
risk aversion. It is further argued that international capital flows have a substantial impact on macroeconomic and financial stability and both GBG and GSG flows have a significant effect on market development. Despite admitting that there is a lot of research surpassed on the phenomenon but one can hardly find any study directly comparing the countries based on official financial flows from international financial institutions. There is a dearth of studies that provide insights into the comparative positions of countries against the financial flows. Therefore, this study is aimed to evaluate worldwide official financial flows by international financial institutions to selected 123 countries of the world. There is a wide array of methodologies to deal with this type of investigation (Niazi et al. 2020; Qazi, et al. 2021) but the most appropriate methodology we find to achieve this objective is GRA. It is a mathematical technique of data analysis espoused in grey systems theory. The remaining part of the study is represented as a literature review, methodology, results, and conclusion.

\section{Literature Review}

Recognizant of the utmost importance of review of existing literature, a comprehensive survey of the literature is conducted. The literature is explored from renowned research databases namely Emerald, Wiley-B lackwell, Elsevier (Science Direct), Taylor \& Francis, and Springer. Highly related studies have been reported here to set the outset of the study. Fischer (2003) analyzed the financial crises faced by Thailand, Korea, Mexico, Indonesia, Russia, Malaysia, and Brazil in 1994-1999 and Argentina, Turkey, and Brazil in 2000-2001 and emphasized the reforms of the international financial system particularly the role of IMF. Gara et al. (2018) proposed a model that identifies factors causing possible illegal financial flows by way of consolidated analysis of discrepancies in trade statistics. Gençsü et al. (2020) buttressed that the European government must weed out by providing subsidies and financial flows viz: fiscal support through tax breaks and budgetary transfer; capital investment and lending to fossil fuel enterprises to meet climate goals. Inekwe et al. (2020) examined financial flow, income inequality, and political situation of the thirty-seven countries of sub-Saharan African regions and concluded that there is no substantial relationship between independent financing access and income inequality; betweenness centrality deteriorates market income inequality and net income; financial integration is advantageous in decreasing income inequality. Klistor in (2019) investigated the reverse and direct financial flows between regions and the federal center of the Russian Federation for the period of the past 20 years. Lemaitre (2019) highlighted illicit financial flows in extractive industries (gas, oil, and mineral) that how stakeholders use legal tools and intermediaries to misuse and manipulate legal frameworks. Lim and Mohapatra (2016) asserted that quantitative easing has a latent impact on observable channels (portfolio balancing, liquidity, and confidence) having significance across diverse types of financial flows. Onanuga et al. (2020) found the short-run positive significant relationship between military expenditure and all financial flow indices (i.e. remittances, portfolio investment, foreign direct investment, and official development assistance) and the long-run negative relationship among upsurge terror incidents, remittances inflow, and foreign direct investment and portfolio investment. Ortega et al. (2019) and Ortega et al. (2020) claimed that there is a significant relationship between illic it financial flows and human development and health services, particularly in low and middle-income countries. Osberghaus, (2019) investigated twenty-one studies of eighteen independent research teams including twelve empirical studies on the impact of natural disaster on financial flows and fluctuations on international trade, and revealed that foreign aid inflows and remittances slightly increase after disasters. Rapanyane et al. (2020) stated that illicit financial flows have a negative effect on country's developmental and governance agenda that must be addressed to curb political and economic instability. Summers (2000) conducted a compressive study on causes, prevention, and cures of international financial crises. A review of the literature helped us to fix the framework of the study. Theoretical foundations of the study, in general, can be traced back in the existing literature but to be more specific we adopted the framework of the study from WDI 2020.

Theoretical Framework: With the careful examination of the data and description of the variables on the website of WDI 2020 it can be found that seven different variables (Table 1) are the key determinants of country-level official financial flows. The definitions and descriptions for the operationalization of variables in this study have been adopted from WDI 2020. 


\begin{tabular}{llll}
\hline Table 1: Variables' Specifications & & \\
\hline Code & Variables & Measure & Criteria \\
\hline $\mathbf{1}$ & World Bank, IDA & Million US Dollars & Larger is the best \\
$\mathbf{2}$ & World Bank, IBRD & Million US Dollars & Larger is the best \\
$\mathbf{3}$ & IMF, Concessional & Million US Dollars & Larger is the best \\
$\mathbf{4}$ & IMF, Nonconcessional & Million US Dollars & Larger is the best \\
$\mathbf{5}$ & Regional development banks, Concessional & Million US Dollars & Larger is the best \\
$\mathbf{6}$ & Regional development banks, Non-concessional & Million US Dollars & Larger is the best \\
$\mathbf{7}$ & Regional development banks, Other institutions & Million US Dollars & Larger is the best \\
\hline & All seven variables possess the characteristic 'Larger & is the best. Therefore for GRA, the \\
study uses the normalization process accordingly. &
\end{tabular}

\section{Methodology}

This cross-sectional study follows positivism as a research philosophy with a deductive approach using secondary data taken from WDI 2020. The overall design of the study comprises a survey of contemporary literature, attaining data and analysis. The survey of the literature is envisaged on renowned research databases aforementioned. GRA is used as a technique of data analysis. The countries included in the analysis were selected based on the availability of relevant data. Variables were decided according to the framework of WDI 2020. GRA was chosen because it can deal with a large number of cross-sections and a multitude of criteria. It also has the privilege to prevail on many statistical techniques because of their limitations and demand for a large amount of data for generating meager results (Girginer \& Uçkun, 2012). GRA progresses stepwise (Kuo et al, 2008; Hamzaçebi \& Pekkaya, 2011; Zhang et al., 2011; Tayyar et al., 2014; Wu, 2002). The procedure applied to proceed to GRA and the notations are adopted from Qazi, et al. (2021), Niazi, et al. (2020), and Ertugrul et al. (2016). GRA proceeds as follows:

Step 1: Extracted the original dataset and the created decision matrix (1).

$$
x_{i}(k)=\left[\begin{array}{ccc}
x_{1}(1) x_{1}(2) & \cdots & x_{1}(m) \\
\vdots & \ddots & \vdots \\
x_{n}(1) x_{n}(2) & \cdots & x_{n}(m)
\end{array}\right]
$$

Table 2: Original Dataset of Official Financing Flows

\begin{tabular}{|c|c|c|c|c|c|c|c|c|}
\hline Sr. & Country & 1 & 2 & 3 & 4 & 5 & 6 & 7 \\
\hline 1 & Afghanistan & -7.8 & 0 & -3.7 & 0 & -10.2 & 0 & 3.1 \\
\hline 2 & Albania & -42 & 81.5 & -6.3 & -0.9 & 0 & 109.5 & -0.2 \\
\hline$\cdots$ & …........ & $\cdots$ & $\cdots$ & $\cdots$ & $\cdots$ & $\cdots$ & $\cdots$ & $\cdots$ \\
\hline$\cdots$ & ........... & $\cdots$ & $\cdots$ & $\cdots$ & $\cdots$ & $\cdots$ & $\cdots$ & $\cdots$ \\
\hline 85 & Pakistan & 129.6 & 53.4 & 0 & -212.4 & -297 & 253.9 & 317.3 \\
\hline 86 & Papua New Guinea & 187.2 & -13.3 & 0 & 0 & 9.6 & 187.3 & 1.7 \\
\hline$\cdots$ & ............ & $\cdots$ & $\cdots$ & $\cdots$ & $\cdots$ & $\cdots$ & $\cdots$ & $\cdots$ \\
\hline ... & ............ & $\cdots$ & $\cdots$ & $\cdots$ & $\cdots$ & $\cdots$ & $\cdots$ & $\ldots$ \\
\hline 122 & Zambia & 132.1 & 0 & 0 & -61.3 & 17.4 & 54.5 & 25.9 \\
\hline 123 & Zimbabwe & & 0 & 0 & & 0 & 0 & -40.8 \\
\hline
\end{tabular}

Source of Data: WDI 2020

Step 2: Created reference-series and comparison matrix (2).

$x_{0}=\left[x_{0}(k) \ldots \ldots \ldots \ldots x_{0}(n)\right]$

(2)

Table 3: Reference and Comparable Sequences

\begin{tabular}{|c|c|c|c|c|c|c|c|c|}
\hline Sr. & Country & 1 & 2 & 3 & 4 & 5 & 6 & 7 \\
\hline $\mathbf{0}$ & Reference Series & 1493.9 & 1625.3 & 148.9 & 28623.2 & 180.9 & 1401.4 & 1057.3 \\
\hline 1 & Afghanistan & -7.8 & 0 & -3.7 & 0 & -10.2 & 0 & 3.1 \\
\hline 2 & Albania & -42 & 81.5 & -6.3 & -0.9 & 0 & 109.5 & -0.2 \\
\hline ... & ........... & $\cdots$ & $\cdots$ & $\cdots$ & $\cdots$ & $\cdots$ & $\cdots$ & $\cdots$ \\
\hline ... & ........... & $\ldots$ & $\ldots$ & $\ldots$ & $\ldots$ & $\ldots$ & $\ldots$ & $\ldots$ \\
\hline 85 & Pakistan & 129.6 & 53.4 & 0 & -212.4 & -297 & 253.9 & 317.3 \\
\hline 86 & Papua New Guinea & 187.2 & -13.3 & 0 & 0 & 9.6 & 187.3 & 1.7 \\
\hline$\cdots$ & ........... & $\cdots$ & $\cdots$ & $\cdots$ & $\cdots$ & $\ldots$ & $\ldots$ & $\cdots$ \\
\hline$\ldots$ & ............ & ... & 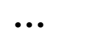 & ... & $\ldots$ & $\ldots$ & ... & $\ldots$ \\
\hline 122 & Zambia & 132.1 & 0 & 0 & -61.3 & 17.4 & 54.5 & 25.9 \\
\hline 123 & Zimbabwe & 0 & 0 & 0 & 0 & 0 & 0 & -40.8 \\
\hline
\end{tabular}

Step 3: Normalized the data (3). 
$x_{i}^{*}(k)=\frac{x_{i}^{(0)}(k)-\min x_{i}^{(0)}(k)}{\max x_{i}^{(o)}(k)-\min x_{i}^{(o)}(k)}$

Table 4: Normalized Comparable Sequences

\begin{tabular}{|c|c|c|c|c|c|c|c|c|}
\hline Sr. & Country & 1 & 2 & 3 & 4 & 5 & 6 & 7 \\
\hline $\mathbf{0}$ & Reference Series & 1.0000 & 1.0000 & 1.0000 & 1.0000 & 1.0000 & 1.0000 & 1.0000 \\
\hline 1 & Afghanistan & 0.3407 & 0.1460 & 0.4825 & 0.0235 & 0.6001 & 0.1916 & 0.4503 \\
\hline 2 & Albania & 0.3257 & 0.1888 & 0.4737 & 0.0235 & 0.6215 & 0.2547 & 0.4486 \\
\hline$\cdots$ & ............ & $\cdots$ & $\cdots$ & $\cdots$ & $\cdots$ & $\cdots$ & $\cdots$ & $\cdots$ \\
\hline$\dddot{85}$ & Pakistan & $\dddot{0} 4010$ & $\dddot{0} 1740$ & $\dddot{04951}$ & $\dddot{0} 0162$ & $\dddot{0} 0000$ & $\dddot{0} 3380$ & $\dddot{06} 6141$ \\
\hline 86 & Papua New Guinea & 0.4263 & 0.1390 & 0.4951 & 0.0235 & 0.6416 & 0.2996 & 0.4495 \\
\hline$\ldots$ & ............ & $\ldots$ & $\ldots$ & $\ldots$ & $\ldots$ & $\ldots$ & $\ldots$ & $\ldots$ \\
\hline$\cdots$ & ........... & $\ldots$ & ... & $\ldots$ & $\ldots$ & $\ldots$ & $\ldots$ & $\ldots$ \\
\hline 122 & Zambia & 0.4021 & 0.1460 & 0.4951 & 0.0214 & 0.6579 & 0.2230 & 0.4622 \\
\hline 123 & Zimbabwe & 0.3441 & 0.1460 & 0.4951 & 0.0235 & 0.6215 & 0.1916 & 0.4274 \\
\hline
\end{tabular}

Step 4: Computed deviation sequence (4).

$\Delta_{0 i}(k)=\left|x_{0}^{*}(k)-x_{i}^{*}(k)\right|$

For biggest deviation (5):

$\Delta_{\max }=\max _{\forall j \varepsilon i} \max _{\forall k}\left|x_{0}^{*}(k)-x_{j}^{*}(k)\right|$

For smallest deviation (6):

$\Delta_{\min }=\min _{\forall j \varepsilon i} \min \left|x_{0}^{*}(k)-x_{j}^{*}(k)\right|$

Table 5: Deviation Sequences

\begin{tabular}{|c|c|c|c|c|c|c|c|c|}
\hline Sr. & Country & 1 & 2 & 3 & 4 & 5 & 6 & 7 \\
\hline $\mathbf{0}$ & Reference Sequence & 0.0000 & 0.0000 & 0.0000 & 0.0000 & 0.0000 & 0.0000 & 0.0000 \\
\hline 1 & Afghanistan & 0.6593 & 0.8540 & 0.5175 & 0.9765 & 0.3999 & 0.8084 & 0.5497 \\
\hline 2 & Albania & 0.6743 & 0.8112 & 0.5263 & 0.9765 & 0.3785 & 0.7453 & 0.5514 \\
\hline$\cdots$ & (........... & $\cdots$ & $\cdots$ & $\cdots$ & $\cdots$ & $\cdots$ & $\cdots$ & $\cdots$ \\
\hline$\ldots$ & ........... & ... & ... & $\ldots$ & ... & ... & ... & ... \\
\hline 85 & Pakistan & 0.5990 & 0.8260 & 0.5049 & 0.9838 & 1.0000 & 0.6620 & 0.3859 \\
\hline 86 & Papua New Guinea & 0.5737 & 0.8610 & 0.5049 & 0.9765 & 0.3584 & 0.7004 & 0.5505 \\
\hline$\cdots$ & ........... & $\cdots$ & $\cdots$ & $\cdots$ & $\cdots$ & $\cdots$ & $\cdots$ & $\cdots$ \\
\hline 122 & Zambia & 0.5979 & 0.8540 & 0.5049 & 0.9786 & 0.3421 & 0.7770 & 0.5378 \\
\hline 123 & Zimbabwe & 0.6559 & 0.8540 & 0.5049 & 0.9765 & 0.3785 & 0.8084 & 0.5726 \\
\hline
\end{tabular}

Step 5: Calculated grey relational coefficient (7). Term $\xi$ is distinguishing co-efficient between 0 and 1 its value noted from literature is 0.5 .

$$
\gamma\left[x_{0}^{*}(k), x_{i}^{*}(k)\right]=\frac{\Delta_{\min }+\xi \Delta_{\max }}{x_{0 i}(k)+\xi \Delta_{\max }}, 0<\gamma\left[x_{o}^{*}(k), x_{i}^{*}(k)\right] \leq 1
$$

Table 6: Grey Relational Co-efficient

\begin{tabular}{|c|c|c|c|c|c|c|c|c|}
\hline Sr. & Country & $\mathbf{1}$ & 2 & 3 & 4 & $\overline{5}$ & 6 & 7 \\
\hline $\mathbf{0}$ & Reference Series & 1.0000 & 1.0000 & 1.0000 & 1.0000 & 1.0000 & 1.0000 & 1.0000 \\
\hline 1 & Afghanistan & 0.4313 & 0.3693 & 0.4914 & 0.3386 & 0.5556 & 0.3821 & 0.4763 \\
\hline 2 & Albania & 0.4258 & 0.3813 & 0.4872 & 0.3386 & 0.5691 & 0.4015 & 0.4755 \\
\hline$\cdots$ & …........ & $\cdots$ & $\cdots$ & $\cdots$ & $\cdots$ & $\cdots$ & $\cdots$ & $\cdots$ \\
\hline$\cdots$ & ........... & $\ldots$ & $\ldots$ & ... & $\ldots$ & ... & ... & ... \\
\hline 85 & Pakistan & 0.4550 & 0.3771 & 0.4976 & 0.3370 & 0.3333 & 0.4303 & 0.5644 \\
\hline 86 & Papua New Guinea & 0.4657 & 0.3674 & 0.4976 & 0.3386 & 0.5824 & 0.4165 & 0.4760 \\
\hline$\cdots$ & ........... & $\cdots$ & $\cdots$ & $\cdots$ & $\cdots$ & $\cdots$ & $\cdots$ & $\cdots$ \\
\hline$\ldots$ & ............ & $\cdots$ & $\cdots$ & $\cdots$ & $\ldots$ & ... & ... & $\ldots$ \\
\hline 122 & Zambia & 0.4554 & 0.3693 & 0.4976 & 0.3382 & 0.5937 & 0.3915 & 0.4818 \\
\hline 123 & Zimbabwe & 0.4326 & 0.3693 & 0.4976 & 0.3386 & 0.5691 & 0.3821 & 0.4662 \\
\hline
\end{tabular}

Step 6: Calculated weighted sum of grey relational co-efficient equation (8) and (9):

$$
\begin{aligned}
& \gamma\left(x_{0}^{*}, x_{i}^{*}\right)=\sum_{k=1}^{n} \beta_{k} \gamma\left[x_{0}^{*}(k), x_{i}^{*}(k)\right] \\
& \sum_{k=1}^{n} \beta_{k}=1
\end{aligned}
$$

Table 7: Grey Relational Grades (GRGs)

\begin{tabular}{lll}
\hline Sr. & Country & GRGs \\
\hline $\mathbf{0}$ & Reference Sequence & 1.0000 \\
$\mathbf{1}$ & Afghanistan & 0.4350 \\
\hline
\end{tabular}




\begin{tabular}{|c|c|c|}
\hline 2 & Albania & 0.4399 \\
\hline$\ldots$ & .......... & $\ldots$ \\
\hline$\ldots$ & ............. & $\ldots$ \\
\hline 85 & Pakistan & 0.4278 \\
\hline 86 & Papua New Guinea & 0.4492 \\
\hline$\cdots$ & .......... & $\ldots$ \\
\hline$\ldots$ & .......... & $\ldots$ \\
\hline 122 & Zambia & 0.4468 \\
\hline 123 & Zimbabwe & 0.4365 \\
\hline
\end{tabular}

\section{Results}

IFIs play a vital role in the socio-economic development of economies and assessment of official financial flows at country levels is a phenomenon of fundamental importance. The objective of the study is thus to evaluate worldwide official financial flows by IFIs to selected countries of the world. Using the GRA (a mathematical technique of data analys is with the capability of handling a multitude of variables, cases, and periods) position of 123 countries has been evaluated based on the criteria of seven variables (Table 1). To make the results more understandable we have classified the countries (Rashid et al., 2021) into seven categories based on the ir GRGs. The classification (Table 8) has been made in form of an ordinal scale i.e. exceptional (countries having GR Gs from 0.4697 to 0.5892 are considered having exceptionally high official financing), excellent (countries having GRGs ranging from 0.4489 to 0.4646 are considered excellent offic ial financing), very good (countries having GRGs ranging from 0.4411 to 0.4487 are considered very good official financing), good (countries having GRGs ranging from 0.4386 to 0.441 are considered good official financing), fair (countries having GRGs ranging from 0.4378 to 0.4386 are considered reasonable official financing), poor (countries having GRGs ranging from 0.4365 to 0.4378 are considered poor official financing) and very poor (countries having GRGs ranging from 0.4092 to 0.4365 are considered very poor offic ial financing). Readers will find the classification helpful in making an informed opinion about a country's official financing support and mechanism.

Table 8: Results of GRA

\begin{tabular}{|c|c|c|c|c|c|c|c|c|}
\hline Country & GRGs & Rank & Country & GRGs & Rank & Country & GRGs & Rank \\
\hline $\begin{array}{l}\text { Reference } \\
\text { Series }\end{array}$ & 1 & 0 & Ghana & 0.4455 & 40 & $\begin{array}{l}\text { Kyrgyz } \\
\text { Republic }\end{array}$ & 0.4381 & 81 \\
\hline Exceptional & & & Azerbaijan & 0.4454 & 41 & Kosovo & 0.438 & 82 \\
\hline Argentina & 0.5892 & 1 & Jordan & 0.4454 & 42 & Comoros & 0.438 & 83 \\
\hline Ethiopia & 0.5726 & 2 & Liberia & 0.4453 & 43 & Jamaica & 0.4379 & 84 \\
\hline Bangladesh & 0.5619 & 3 & Georgia & 0.4445 & 44 & Congo, Rep. & 0.4379 & 85 \\
\hline India & 0.5414 & 4 & Mauritania & 0.4443 & 45 & $\begin{array}{l}\text { The Syrian } \\
\text { Arab Republic }\end{array}$ & 0.4379 & 86 \\
\hline $\begin{array}{l}\text { Egypt, Arab } \\
\text { Rep. }\end{array}$ & 0.5236 & 5 & Mozambique & 0.4442 & 46 & Eswatini & 0.4379 & 87 \\
\hline Kenya & 0.5231 & 6 & Paraguay & 0.4434 & 47 & Algeria & 0.4378 & 88 \\
\hline Costa Rica & 0.5204 & 7 & Guinea & 0.4429 & 48 & Somalia & 0.4378 & 88 \\
\hline Vietnam & 0.5174 & 8 & Benin & 0.4427 & 49 & Serbia & 0.4378 & 90 \\
\hline Chad & 0.5097 & 9 & Dominican Republic & 0.4423 & 50 & Poor & & \\
\hline Tanzania & 0.4954 & 10 & Senegal & 0.4417 & 51 & $\begin{array}{l}\text { St. Vincent and } \\
\text { the Grenadines }\end{array}$ & 0.4378 & 91 \\
\hline Colombia & 0.4952 & 11 & Sri Lanka & 0.4414 & 52 & Haiti & 0.4378 & 92 \\
\hline Uzbekistan & 0.4926 & 12 & Angola & 0.4413 & 53 & Turkmenistan & 0.4377 & 93 \\
\hline Nepal & 0.4918 & 13 & Togo & 0.4411 & 54 & St. Lucia & 0.4376 & 94 \\
\hline Indonesia & 0.4907 & 14 & Good & & & Guyana & 0.4374 & 95 \\
\hline Nigeria & 0.4849 & 15 & Timor-Leste & 0.441 & 55 & Eritrea & 0.4374 & 96 \\
\hline Rwanda & 0.483 & 16 & Moldova & 0.4408 & 56 & Morocco & 0.4374 & 97 \\
\hline Cameroon & 0.471 & 17 & $\begin{array}{l}\text { Bosnia and } \\
\text { Herzegovina }\end{array}$ & 0.4404 & 57 & Dominica & 0.4373 & 98 \\
\hline Uganda & 0.4697 & 18 & Honduras & 0.4403 & 58 & Montenegro & 0.4373 & 99 \\
\hline Excellent & & & Guinea-Bis sau & 0.4402 & 59 & El Salvador & 0.4373 & 100 \\
\hline Brazil & 0.4646 & 19 & Albania & 0.4399 & 60 & Tajikistan & 0.4373 & 101 \\
\hline Turkey & 0.4644 & 20 & Sierra Leone & 0.4398 & 61 & $\begin{array}{l}\text { Solomon } \\
\text { Islands }\end{array}$ & 0.4372 & 102 \\
\hline Ecuador & 0.459 & 21 & Bhutan & 0.4396 & 62 & Guatemala & 0.437 & 103 \\
\hline
\end{tabular}




\begin{tabular}{|c|c|c|c|c|c|c|c|c|}
\hline China & 0.4587 & 22 & Maldives & 0.4394 & 63 & Yemen, Rep. & 0.4369 & 104 \\
\hline Philippines & 0.4563 & 23 & Congo, Dem. Rep. & 0.4393 & 64 & Samoa & 0.4368 & 105 \\
\hline Niger & 0.4554 & 24 & Thailand & 0.4391 & 65 & Mauritius & 0.4368 & 106 \\
\hline Mali & 0.4544 & 25 & The Gambia, The & 0.4391 & 66 & $\begin{array}{l}\text { North } \\
\text { Macedonia }\end{array}$ & 0.4367 & 107 \\
\hline Madagascar & 0.4533 & 26 & $\begin{array}{l}\text { Sao Tome and } \\
\text { Principe }\end{array}$ & 0.4388 & 67 & $\begin{array}{l}\text { Iran, Islamic } \\
\text { Rep. }\end{array}$ & 0.4365 & 108 \\
\hline Cote d'Ivoire & 0.4526 & 27 & Djibouti & 0.4388 & 68 & Very Poor & & \\
\hline $\begin{array}{l}\text { Venezuela, } \\
\text { RB }\end{array}$ & 0.4523 & 28 & Lebanon & 0.4387 & 69 & Zimbabwe & 0.4365 & 109 \\
\hline Bolivia & 0.4512 & 29 & $\begin{array}{l}\text { The central African } \\
\text { Republic }\end{array}$ & 0.4387 & 70 & $\begin{array}{l}\text { Russian } \\
\text { Federation }\end{array}$ & 0.4352 & 110 \\
\hline Mexico & 0.4506 & 30 & Sudan & 0.4387 & 71 & Botswana & 0.4352 & 111 \\
\hline Malawi & 0.4501 & 31 & Lao PDR & 0.4386 & 72 & Afghanistan & 0.435 & 112 \\
\hline Mongolia & 0.4495 & 32 & Fair & & & Bulgaria & 0.4345 & 113 \\
\hline Cambodia & 0.4495 & 33 & Vanuatu & 0.4386 & 73 & South Africa & 0.4341 & 114 \\
\hline $\begin{array}{l}\text { Papua New } \\
\text { Guinea }\end{array}$ & 0.4492 & 34 & Lesotho & 0.4385 & 74 & Burundi & 0.4338 & 115 \\
\hline Nicaragua & 0.449 & 35 & Fiji & 0.4385 & 75 & Belarus & 0.4332 & 116 \\
\hline $\begin{array}{l}\text { Burkina } \\
\text { Faso }\end{array}$ & 0.4489 & 36 & Grenada & 0.4384 & 76 & Kazakhstan & 0.432 & 117 \\
\hline Very Good & & & Cabo Verde & 0.4383 & 77 & Armenia & 0.4316 & 118 \\
\hline Tunisia & 0.4487 & 37 & Gabon & 0.4383 & 78 & Pakistan & 0.4278 & 119 \\
\hline Myanmar & 0.4473 & 38 & Belize & 0.4382 & 79 & Peru & 0.4257 & 120 \\
\hline Zambia & 0.4468 & 39 & Tonga & 0.4382 & 80 & $\begin{array}{l}\text { Romania } \\
\text { Ukraine }\end{array}$ & $\begin{array}{l}0.4242 \\
0.4092\end{array}$ & $\begin{array}{l}121 \\
122\end{array}$ \\
\hline
\end{tabular}

Argentina, Ethiopia, Bangladesh, India, Egypt, Arab Rep., Kenya, Costa Rica, Vietnam,

Chad, Tanzania, Colombia, Uzbekistan, Nepal, Indonesia, Nigeria, Rwanda, Cameroon, and Uganda have exceptionally high GRGs. Brazil, Turkey, Ecuador, China, Philippines, Niger, Mali, Madagascar, Cote d'Ivoire, Venezuela, RB Bolivia, Mexico, Malawi, Mongolia, Cambodia, Papua New Guinea, Nicaragua, and Burkina Faso have excellent GRGs. Tunisia, Myanmar, Zambia, Ghana, Azerbaijan, Jordan, Liberia, Georgia, Mauritania, Mozambique, Paraguay, Guinea, Benin, Dominican Republic, Senegal, Sri Lanka, Angola, and Togo fall under very good ensign. Timor-Leste, Moldova, Bosnia and Herzegovina, Honduras, Guinea-Bissau, Albania, Sierra Leone, Bhutan, Maldives, Congo, Dem. Rep., Thailand, Gambia, The Sao Tome and Principe, Djibouti, Lebanon, Central African Republic, Sudan, and Lao PDR come into the category of good. Vanuatu, Lesotho, Fiji, Grenada, Cabo Verde, Gabon, Belize, Tonga, Kyrgyz Republic, Kosovo, Comoros, Jamaica, Congo, Rep. Syrian Arab Republic, Eswatini, Algeria, Somalia, and Serbia have fair grade. St. Vincent and the Grenadines, Haiti, Turkmenistan, St. Lucia, Guyana, Eritrea, Morocco, Dominica, Montenegro, El Salvador, Tajikistan, Solomon Islands, Guatemala, Yemen, Rep., Samoa, Mauritius, North Macedonia and Iran, Islamic Rep. have poor GRGs. Zimbabwe, Russian Federation, Botswana, Afghanistan, Bulgaria, South Africa, Burundi, Belarus, Kazakhstan, Armenia, Pakistan, Peru, Romania, and Ukraine have very poor GRGs in official financial flows. From the result of GRA, it can also be learned that most of the countries under exceptionally high GRGs are member countries of the South Asian Association for Regional Cooperation (SAARC). Under the excellent ensign, mostly are member countries of the Union of South American Nations (UNASUR). Under ensign of very good, mostly are member countries of West African Economic and Monetary Union (WAEMU). Under ensign of good, mostly are Arabian Countries (AC). Under ensign of fair, mostly are member countries of Southern Africa Development Community (SADC). Under the ensign of poor, mostly are member countries of Caribbean Community and Common Market (CARICOM). Under ensign of very poor, mostly are member countries of Economic Cooperation Organization (ECO). The countries having high GRGs are considered as the countries having an effective system of official financial flows from IFIs and foreign governments for socio-economic development. The countries having low GRGs are considered to be the countries having a weak and relatively less effective system of official financial flows from IFIs and foreign government so far.

\section{Conclusion}

IFIs and foreign governments are major contributors to the development of countries. International funding is an issue of vital importance and it is high on the agenda of contemporary research. 
Country-level comparative analysis of multiple cross-sections with a multitude of criteria is imperative therefore the aim of the study is to evaluate worldwide official financial flows by IFIs to selected 123 countries. The design of the study is a review of literature, extraction data from WDI 2020, and mathematical analysis. A classical procedure of GRA (a mathematical technique of data analysis) has been applied. The results of the study show that Argentina, Ethiopia, Bangladesh, India, Egypt, Arab Rep., Kenya, Costa Rica, Vietnam, Chad, Tanzania, Colombia, Uzbekistan, Nepal, Indonesia, Nigeria, Rwanda, Cameroon, and Uganda has exceptionally high GRGs. Most of the countries under exceptionally high GRGs are member countries of the South Asian Association for Regional Cooperation (SAARC). St. Vincent and the Grenadines, Haiti, Turkmenistan, St. Lucia, Guyana, Eritrea, Morocco, Dominica, Montenegro, El Salvador, Tajikistan, Solomon Islands, Guatemala, Yemen, Rep., Samoa, Mauritius, North Macedonia and Iran, Islamic Rep. have poor GRGs. Zimbabwe, Russian Federation, Botswana, Afghanistan, Bulgaria, South Africa, Burundi, Belarus, Kazakhstan, Armenia, Pakistan, Peru, Romania, and Ukraine have very poor GRGs in official financial flows. Under the ensign of poor, mostly are member countries of Caribbean Community and Common Market (CARICOM). Under ensign of very poor, mostly are member countries Economic Cooperation Organization (ECO). The study contributes to the existing literature by way of providing a deep understanding of the phenomenon. It contributes a lot of new valuable information on the phenomenon in form of assigning GRGs to countries, ranking of the countries, and their classifications. This study has profound theoretical and practical implications for political governments, economic policymakers, IFIs, researchers, and academia by way of enabling them to form informed opinions. This study has some limitations as well. Firstly, it is a cross-sectional study therefore it is recommended that future studies should be designed on a longitudinal design using time series/panel data. Secondly, it uses GRA as a hierarchicalization technique there is an array of such techniques (SWARA, VIKOR, ISM, RIDIT, AHP, TOPSIS, etc.) future studies may choose from these methodologies. Thirdly, equal weights have been given to all variables, in future studies, this scheme may be changed by using the Entropy method.

\section{References}

Adeleke, F. (2019). Illicit financial flows and inequality in Africa: How to reverse the tide in Zimbabwe. South African Journal of International Affairs, 26(3), 367-393.

Bayoumi, T., Gagnon, J., \& Saborowski, C. (2015). Official financial flows, capital mobility, and global imbalances. Journal of International Money and Finance, 52, 146-174.

Carnevali, E., Dele idi, M., Pariboni, R., \& Passarella, M. V. (2020). Cross-border financial flows and global warming in a two-area ecological SFC model. Socio-Economic Planning Sciences, 100819.

Cova, P., \& Natoli, F. (2020). The risk-taking channel of international financial flows. Journal of International Money and Finance, 102, 102096.

Ertugrul, I., Oztas, T., Ozcil, A., \& Oztas, G. Z. (2016). GRA approach in an academic performance comparison of university: A case study of Turkish universities. European Scientific Journal, 7881, 128-139.

Fischer, S. (2003). Financial crises and reform of the international financial system. Review of World Economics, 139(1), 1-37.

Gara, M., Giammatteo, M., \& Tosti, E. (2018). Magic mirror in my hand.... How to trade mirror statistics can help us detect illegal financial flows. World Econ., 42, 3120-3147.

Gençsü, I., Whitley, S., Trilling, M., van der Burg, L., McLynn, M., \& Worrall, L. (2020). Phasing out public financial flows to fossil fuel production in Europe. Climate Policy, 20(8), 10101023.

Girginer, N., \& Uçkun, N. (2012). The financial performance of the commercial banks in crisis period: evidence from Turkey as an emerging market. European Journal of Business and Management, 4(19), 19-36.

Hamzaçebi, C., \& Pekkaya, M. (2011). Determining of stock investments with GRA. Expert Systems with Applications, 38(8), 9186-9195.

Inekwe, J. N., Jin, Y., \& Valenzuela, M. R. (2020). Income inequality, financial flows, and political institution: sub-Saharan African financial network. Empirical Economics, 58(6), 2635-2665.

Klistorin, V. I. (2019). Interlevel financial flows in the budget system of the Russian Federation. Regional Research of Russia, 9(2), 118-125. 
Kuo, Y., Yang, T., \& Huang, G. W. (2008). The use of GRA in solving multiple attribute decisionmaking problems. Computers \& Industrial Engineering, 55(1), 80-93.

Lemaître, S. (2019). Illicit financial flows within the extractive industries sector: a glance at how legal requirements can be manipulated and diverted. Crime, Law and Social Change, 71(1), 107128.

Lim, J. J., \& Mohapatra, S. (2016). Quantitative easing and the post-crisis surge in financial flows to developing countries. Journal of International Money and Finance, 68, 331-357.

Niazi, A. A. K., Asghar, W., Basit, A., \& Qazi, T. F. (2020). Composite Appraisal of Women Development in Selected Thirty-six Countries with Special Focus on Pakistan: Applying Grey Incidence Analys is Model. Journal of Business and Social Review in Emerging Economies, 6(4), 1227-1236.

Onanuga, A. T., Odusanya, I. A., \& Adekunle, I. A. (2020). Terrorism and financial flows in Africa. Behavioral Sciences of Terrorism and Political Aggression, 1-18.

Ortega, B., Sanjuán, J., \& Casquero, A. (2019). Illicit Financial Flows Another Road Block to Human Development in Low-and Middle-Income Countries. Social Indicators Research, 142(3), 1231-1253.

Ortega, B., Sanjuán, J., \& Casquero, A. (2020). Illicit financial flows and the provision of child and maternal health services in low-and middle-income countries. BMC International Health and Human Rights, 20(1), 1-19.

Osberghaus, D. (2019). The effects of natural disasters and weather variations on international trade and financial flows: a review of the empirical literature. Economics of Disasters and Climate Change, 3(3), 305-325.

Qazi, T. F., Niazi, A. A. K., Asghar, W., \& Basit, A. (2021). Ease of Doing Business: Analysis of Trade Facilitations of One Hundred Twenty-Seven Countries of the World. Journal of Accounting and Finance in Emerging Economies, 7(1), 65-75.

Rapanyane, M. B., \& Ngoepe, C. C. (2020). The impact of illicit financial flows on the South African political economy under Jacob Zuma, 2009-2018. Journal of Public Affairs, 20(2), e2020.

Rashid, M. K., Basit, A., Qazi, T. F., \& Niazi, A. A. K. (2021). Comprehensive Analysis of Tariff Barriers Worldwide: A Composite Assessment Approach. Journal of Accounting and Finance in Emerging Economies, 7(1), 205-215.

Summers, L. H. (2000). International financial crises: causes, prevention, and cures. American Economic Review, 90(2), 1-16.

Tayyar, N., Akcanl, F., Genç, E., \& Erem, I. (2014). Evaluating the financial performance of companies operating in the field of informatics and technology registered in BIST by analytical hierarchy process (AHP) and gray relational analysis (TIA) method. Accounting and Finance Journal, 61, 19-40.

WDI (2020). Retrieved April 15, 2020, from http://wdi.worldbank.org/tables

Wu, H. H. (2002). A comparative study of using GRA in multiple attribute decision-making problems. Quality Engineering, 15(2), 209-217.

Zhang, S. F., Liu, S. Y., \& Zhai, R. H. (2011). An extended GRA method for MCDM with intervalvalued triangular fuzzy assessments and unknown weights. Computers \& Industrial Engineering, 61(4), 1336-1341. 